\title{
Dislocating the self: anthropological field work in the Kimberley, Western Australia, 1934-1936
}

\author{
Geoffrey Gray
}

The anthropologist Phyllis Kaberry, author of the now classic study, Aboriginal woman: sacred and profane, was a young and inexperienced researcher when she first went to the field between March and November 1934 and again between May 1935 and June 1936. The Australian National Research Council (ANRC) funded her research, acting on the advice of its Committee for Anthropology, chaired by AP Elkin. ${ }^{1}$ Elkin, Professor of Anthropology in the only teaching department of anthropology in an Australian university, had control not only over where research was conducted but also over who could conduct that research. Despite the discipline's youth - the chair had been founded in 1925 - a structure and unwritten rules governing the behaviour of anthropologists in the field had already been developed, as well as a methodological approach to field work, driven by an interest in 'traditional' Aboriginal social and cultural practices and institutions rather than the contemporary everyday circumstances of Aboriginal people. ${ }^{2}$ WEH Stanner, a contemporary of Phyllis Kaberry, described the dilemma:

I had been taught to turn my back on the speculative reconstruction of the origins and development of primitive institutions, and to have an interest only in their living actuality ... [but] an interest in 'living actuality' scarcely extended to the actual life-conditions of the aborigines. ${ }^{3}$

The containment of criticism of government policy and practice went hand-inhand with this limited research focus. Kaberry's research was framed within this discourse - and its consequent limitations - and a concomitant realisation that they were a pre-requisite to a future career in anthropology in Australia.

\section{To that scientific task I stuck}

In Australia, particularly during the first half of the twentieth century, the then new discipline of social anthropology was recognised as one that could help colonial (native)

1. The ANRC was responsible for the distribution of funds from the American philanthropic Rockefeller Foundation (see Mulvaney 1988).

2. Mulvaney 1988; Gray 1994.

3. Stanner 1969: 14. 
administrations - especially in the Australian territory of Papua, and after $1921 \mathrm{New}$ Guinea - in their control, management and development of Indigenous peoples, as well as assisting Indigenous people both in Papua and New Guinea and on the Australian mainland 'in the task of adjusting themselves to the great changes which have come upon them'. ${ }^{4}$ Anthropology, one of its main proponents argued, was 'engaged in work which is of fundamental importance for all who, like the missionaries, seek to influence the aborigines and to modify their culture. It endeavours to supply detailed knowledge of native social life in all its ramifications, and so to be in the position to offer suggestions [to government and mission] with regard to changes which are considered desirable'. ${ }^{5}$ Anthropology could also be a guardian overseeing 'the weaknesses, anomalies and injustices in law and administration regarding [Indigenous peoples]' ${ }^{6}$

The discipline developed a discourse of understanding native peoples and helping colonial administrations that emphasised the practical usefulness of anthropology; this was fundamental in convincing both Australian State and Commonwealth governments to support the anthropological enterprise, culminating in the establishment in 1925 of a Chair of Anthropology at the University of Sydney, funded by a combination of Commonwealth and State funding and subsidised pound for pound by the American Rockefeller Foundation. ${ }^{7}$ It was the only teaching department of anthropology in an Australian university until a department was established at the University of Western Australia in 1956. In effect, what anthropology promised those governing indigenous peoples was a new beginning, and this was attractive to governments under increasing international, national and local scrutiny over the conditions and treatment of indigenous people within their jurisdictions. ${ }^{8}$ Governments, seeing their own interests served, therefore facilitated access to the subjects of anthropology. In this way, anthropology depended upon the goodwill of the government and thus was implicated in the colonial enterprise. ${ }^{9}$

To maintain access to the field, anthropologists were generally obliged to restrict criticism of the conditions and treatment of Aboriginal people to within the funding body or the sponsoring university, which was then expected to pass it on to the government department concerned with Aboriginal affairs. For instance, Raymond Firth, acting Professor of Anthropology at the University of Sydney, advised that 'any cruelty to natives observed during research should not be reported until after the research is concluded'. Firth was concerned that future anthropological research could be blocked by a public row or departmental indignation over charges of ill treatment of Aboriginal people. ${ }^{10}$ On the occasions that anthropologists had publicly questioned or been critical

4. Elkin 1938: v.

5. Elkin 1935a: 34.

Elkin to Fitzpatrick, 28 November 1946, copy in Thomson Collection, Museum of Victoria.

Mulvaney 1998; Gray 1997(a): 27-29.

See for example Reynolds 1998; Paisley 2000.

The argument that anthropology was the 'handmaiden' of colonialism, or that anthropology needed colonial governments has been much debated. See for example Asad (ed) 1973; Thomas, N 1994; Kuper 1996.

10. Firth, 'Notes on Anthropological Field Work near Broome', 3 May 1932. Elkin Papers (EP), University of Sydney, 161/4/1/85; also Firth to Gray, 20 February 1993, in author's possession. 
of specific government actions, or they had reported instances of abuse to government agents - usually the Chief Protector of Aborigines in the State or Territory - the government had taken offence, research had become threatened and good relations had had to be re-established. ${ }^{11}$ On other occasions, the government could be direct, for example SD Porteus, professor of Clinical Psychology in the University of Hawaii, who conducted psychological investigation among Aboriginal people in northwest Western Australia in the late 1920s, guaranteed the Western Australian government that any material they had filmed 'would [not] in any way reflect upon the handling of the natives' in that State. $^{12}$

To be sure, the anthropological field site was intensely racialised and political, ${ }^{13}$ yet much ethnographic writing in Australia for the greater part of the first half of the twentieth century presented a political and social reality in which it appeared that Aboriginal people were insulated from the changes brought about by settler, pastoralist, mission and government. Julie Marcus, for example, observed that the failure to explore the racist nature of the Australian state in most Aboriginal ethnography derives from that state power' and a reluctance to bring this power and violence into view. ${ }^{14}$ Although anthropologists did not write about such social and political realities (and the power of the state) in their ethnographies, which were 'scientific' works, they were aware of these changes and their effects on Aboriginal people's cultural lives and their social and political organisation. For example, in 1928 the Melbourne anthropologist Donald Thomson told AR Radcliffe-Brown, foundation Professor of Anthropology in the University of Sydney, that his research in Cape York, northern Queensland, had 'been rather broken and disappointing, on account of the extreme disorganisation of the natives' ${ }^{15}$ Ursula McConnel, who had worked in the same area a year earlier, made similar observations. ${ }^{16}$ Elkin, an early researcher with the Australian National Research Council, commented that when he was in the northwest of Western Australia in 1928,

the Ungarinyin (Ngarinjin) and Wunambal were hardly effected at all by contact, though the Worora were being influenced by the Presbyterian Mission on their coastal border, but not drastically. I was actually living in a 'stone age', that is, with a food gathering and hunting people who relied solely on stone, bone and wood for tools and weapons. However, because of depopulation and lack of progress, both the Mission to the Worora and a Government Station in Ungarinyin (Ngarinjin) territory were closed after the War and the people moved south and finally settled at Mowanjum in 1952. Thus in the space of little more than twenty years, the local and economic organization of these tribes and their tie to the land had been utterly changed, and a new tri-tribal group began to develop in an artificial situation. Although the social organization and culture generally of

11. Gray 1994: 217-245; Marcus 1987: 185-197; Donald Thomson also encountered opposition when he provided evidence of abuse on Arukun Mission, North Queensland (Thomson 1983: 5-6).

12. Porteus to Neville, 20 November, 1928. Western Australia State Archives (WASA), ACC 993 $133 / 28$.

13. Cowlishaw 1997: 95; Gledhill 2000: passim.

14. Marcus 1992: 100.

15. Donald Thomson to AR Radcliffe-Brown, 14 August 1928, National Library of Australia (NLA), Australian National Research Council (ANRC) Papers, MS 482, 832.

16. Various in NLA, MS 482, 834. 
the three tribes was basically the same, the new situation will be reflected in kinship and marriage rules and social behaviour. ${ }^{17}$

Anthropologists during the period under discussion were mostly reluctant to publicly discuss the forms of interaction on colonial frontier society or if they did it was in fora outside the discipline's boundaries, even though 'culture contact' was an interest of anthropologists in the 1930s. Many tended to express the contemporary social reality elsewhere: in private correspondence, diaries, field notes and confidential reports to funding institutions and mission bodies. ${ }^{18}$ Most, if not all, anthropologists were neither overtly critical of the colonial regime in which they worked in their published works, nor were they driven by humanitarian ideals, although they saw themselves as enlightened members of the community when it came to race relations because of their special relations with indigenous peoples. Some present day anthropologists express the view that anthropologists were distrusted (if not disliked) by governments then as now, as if there is a natural antipathy between administrative interests and academic (anthropological) interests. ${ }^{19}$

When I asked Raymond Firth, in 1993, 'why Australian [anthropologists] were so supine when it came to public criticism of the treatment, conditions and welfare of Australian Aborigines' particularly in the $1930 \mathrm{~s},{ }^{20}$ he chided me as being a 'bit anachronistic' for decrying the 'supineness' of anthropologists sixty years ago. 'It is easy to say this now, but I wonder what you would have done ... if you had been responsible for a research programme' ${ }^{21}$ I replied that it appeared from his comments that the research programme of describing Aboriginal life 'before it was too late', took precedence over the well-being of Aboriginal people. Some years later Firth was keen to press the argument that while anthropologists of 'the early period [1920s and 1930s] could have advocated the Aboriginal cause more openly ... [they were] not silent witnesses of injustice ... [Nevertheless], they saw their job as anthropology, the study of human social behaviour in all its variety, as the pursuit and presentation of knowledge, not propaganda' 22

Anthropologists believed that the scientific method would provide both an explanation and the solution to the future of Aboriginal and other indigenous peoples. The

17. Elkin 1965: 13-14.

18. For example Elkin's report to the Australian Board of Missions (ABM) on Ernest Gribble and his running of the Forrest River Mission. Elkin was so sensitive about this that he was anxious, some 15 years after he made the report, that it be made public. Australian Board of Missions (ABM) Papers, Mitchell Library. See also reports and correspondence of Elkin, Piddington, Warner, Stanner, Hart, McConnel. ANL, ANRC Papers, MS 482.

19. The idea of a natural antipathy between anthropologists and government is strongly held and expressed in contemporary discourses about anthropology. Several referees, primarily anthropologists, of both this paper and others of mine have expressed similar views, such as: 'anthropologists were considered [then, as now] dangerous radicals who supported the interests of primitive people against those of the civilising nation builders and missionaries'. Anonymous referee, January 2002. Marcus, in contrast argues that the 'state exercises power to produce both Aboriginal and anthropological selves and the texts, through which each shall be known' (Marcus 1992: 100); see also Asad and others 1973; McKnight 1990: 55ff but cf 43; Gray 1997b: 128-130; 1998: 37-61; Gledhill 2000.

20. Gray 1994: 217.

21. Firth to Gray, February 1993. 
British Under-secretary of State for Colonies was quoted approvingly by the Australian anthropologist H Ian Hogbin in a series of articles - 'Anthropology and the native problem' - published in 1932 for the Sydney Morning Herald: he too saw the value of anthropology:

If we are to succeed in our duties towards native peoples, as rulers, as missionaries, or as instruments for the advance of civilisation, we must study them objectively and base our policy on real understanding acquired not only from personal contact, but from scientific study of their mental and moral characteristics, of native law and custom, of native history, language and traditions. Native methods of agriculture, native arts and crafts, should be examined scientifically before any attempt is made to supersede what we find existing. Herein lies the importance of anthropological work, an importance which is difficult to over-estimate. ${ }^{23}$

It could be argued that anthropologists were trying to establish an understanding of a society that was otherwise considered to be irrational, backward and primitive. This was in accordance with their perception of themselves as scientists using a method which was implicitly based on a neutral, value-free science, above and beyond politics, which could provide benefit to government, mission, settler and Aboriginal people alike. Radcliffe-Brown, in an address to the 1926 Australasian Association for the Advancement of Science, stated that 'it is the day for scientific service, and science must ... take a hand in the regeneration of [native] people. ... [I]ndeed ... had scientifically trained minds taken a hand in all past endeavours to ameliorate these people the [present] result might have been very different' ${ }^{24}$ Lloyd Warner, a student of RadcliffeBrown, observed that 'he [Radcliffe-Brown] treats the human native as the chemist does his substance ... if he admits human sympathies and interests, he impairs the validity of his work. He then becomes a human being. The ideal anthropologist must not judge "this is good, or this is bad", he must only record and deduce' ${ }^{25}$ Elkin, writing of his field work in northwest Western Australia in 1927, emphasised that he had 'no humanitarian motive ... My task was to record and analyse aboriginal social organisation,

22. Firth 1998: 42; see also Cocks 1994. When working for Vesteys in the mid-1940s, Ronald and Catherine Berndt were confronted by such a choice when the conditions and treatment of Aboriginal workers at Birrundudu, a Vesteys outstation, had been brought to the attention of the Administrator of the Northern Territory, CLA Abbott, by an officer the Native Affairs Branch, Bill Harney; should they support Harney or stay silent? 'It seems to us that if we are either to evade, or to keep silent regarding, such accusations as we understand Harney to have made, then at the termination of our work with Vesteys there will be no avenues open to us in the field of anthropology'. Ronald Berndt to Elkin, 10 July 1945. EP: 246/613. They remained silent and the welfare of Aboriginal people were subordinated to their future career.

23. Hogbin 1932. Both Elkin's and Hogbin's view of the value of anthropology share some of the ideals of the civilising enterprise of the Christian missions. Cf Burridge, 1973. Elkin, undoubtedly influenced by his training as an Anglican priest, developed close relationships with both mission groups and humanitarian movements. Canon Needham, national secretary of the Association for the Protection of Native Races (APNR), laid down the general principle that there needed to be a close co-operation between government and mission. Elkin, as an Anglican priest, member of the Anglican Australian Board of Missions from the early 1930s and as president of the APNR from 1933, was no doubt influenced by Needham's principle. See 'Conference of Secretaries and Missionary Leaders, Sydney 25-28 April 1944', report by Theile, in Correspondence FO Theile and JJ Stolz, UELCA Archives, Adelaide.

24. Quoted Jacobs 1990: 130.

25. Warner et al 1928: 68 
ritual and mythology and to that [scientific] task I stuck' ${ }^{26}$ Stanner, writing about his early work in Port Keats and Daly River, said that the idea that he, as an anthropologist, should study Indigenous people's "living actuality" scarcely extended to the actual life conditions of the aborigines ... We thought it our task to salvage pieces of information and from them try to work out the traditional social forms' ${ }^{27}$

The incongruity was that anthropologists believed that the lifeways (culture) of Australian Aboriginal people were under threat of extinction and therefore needed immediate capture and description. In these circumstances it could be understood that opportunism and political expediency appeared to direct the disciplinary practices of anthropology and research rather than the individual anthropologist. As I suggested above, anthropologists were reluctant to describe the social and political realities of a colonised people, but instead described what might be thought of as a 'double' reconstruction - the 'pristine' (before contact) culture and the 'ideal frontier' (at the point of contact). In this way anthropologists provided an 'alternative now', which looked backwards to the past rather than looking at the present, and thus anthropology theorised itself into an 'idealised space' ${ }^{28}$ The future was an imagined place of cultural disintegration. This brings into focus the seemingly paradoxical purpose of pre-1950 Australian anthropology: its desire to study the 'primitive' - the 'full-blood' Aboriginal person - and at the same time act as an agent of modernity by assisting governments and missions in their formulations of policy and the training of their personnel. (Of course how to do it, and the role of the anthropologist in this, was problematic). Missions, on the other hand, desired to show the progress from 'primitive' to 'Christian citizen', which meant the modification and sometimes the erasure of Indigenous cultural and social life, and the degree to which it was altered reflected the scope of their efforts and success. Matters to do with the effects of dispossessory occupation in the Australian context, especially in the southeast and southwest - 'settled' Australia were reflected in a lack of interest for an ethnography based on 'acculturated' or 'partAborigines'. 29

As a consequence of all of this, there are a number of factors which affected the way anthropologists worked and the way anthropological knowledge was produced. Firstly, anthropologists were inevitably compromised by needing to obtain permission and approval of the government to conduct research, which applied to research in all States and Commonwealth Territories. The compromise - finding a balance between the competing interests - was both political, in order to get funding and access to the field, and intellectual, in so far as the object of interest - the 'pristine primitive' or the 'savage savage' - could be studied. ${ }^{30}$ The utilitarian nature of the research was highlighted, hence anthropologists stated they would study 'culture contact', 'culture change', in effect 'applied anthropology', which would be of benefit to governments in

26. Elkin 1962: 212.

27. Stanner 1969: 14

28. Some anthropologists even marked their being 'first' by erasing previous anthropological researchers accounts and in the case of Donald Thomson in Arnhem Land, naming and mapping the area. See especially Thomson 1948-49.

29. Cowlishaw 1987: 221-237; Marcus 1992; Gray 2000: 176-200; Elkin 1965: 22-23.

30. H Ian Hogbin commented to Elkin: 'I mourn a little bit because I am not studying the real savage savage' Hogbin to Elkin, 15 August 1933, Hogbin Papers, University of Sydney Archives. 
the management and advancement of Aboriginal people in remote Australia. These arguments were then reiterated by the officials of funding bodies such as the Australian National Research Council (ANRC) in its correspondence with government seeking permission for their researchers. ${ }^{31}$ Most anthropologists in the pre-war period were not, however, interested in the analysis of the relations between Aboriginal people and settlers on the frontier or in settlements: their interest was rather in the analysis of 'traditional' culture.

Secondly, as a result of attempting to find a balance between the demands of governments, the requirements of their science, and their membership of the colonial society, anthropologists were often placed in ambiguous situations. Anthropologists possessed knowledge about Indigenous people that inadvertently produced a moral dimension to their work which was seemingly denied to others who worked in native affairs. 'Anthropologists', Reo Fortune told his readers, 'make public information of facts which native reticence would else have kept private and unknown'. ${ }^{32}$ These facts once made public, had the potential to be used against the interests of Indigenous peoples, especially if they revealed that they were engaging in actions - such as sorcery detrimental to the maintenance of the good order of government. ${ }^{33}$ What Fortune saw as a potential dilemma, Hogbin saw as an opportunity for anthropology. He offered a view that anthropologists, 'men trained in scientific method', were like 'consulting physicians to colonial Governments' who by 'their knowledge of native customs and institutions ... are in a position to advise [governments] on native problems, as, for instance, the decline in aboriginal population or native unrest ${ }^{\prime 34}$ It is unclear if Hogbin was implying that there was an illness in the colonial order at the time which anthropology could help diagnose and heal; he did however suggest to Elkin that 'we [anthropologists] have [native] problems to find solutions for' ${ }^{35}$

Thirdly, governments needed assurance that anthropologists would not cause problems by bringing matters to do with the treatment and conditions of Aboriginal people to public attention. This had the potential to restrict anthropologists' public criticism of the colonial enterprise and its effects on Aboriginal people, such as Piddington's experience demonstrated, despite anthropologists sometimes declaring themselves as being on the side of Indigenous people and representing Aboriginal interests to government and its agents. For example, Ronald Berndt stated that the anthropologists were on the 'side of the underdog' by 'representing the virtually inarticulate Aborigines'; ${ }^{36}$ Fortune declared that the anthropologist was a 'friend of the native' and did not betray them to the administration. ${ }^{37}$ This does not imply that

31. See various applications in ANL, MS 482.

32. McLean 1992: 51.

33. Gray 1999: 56-76; 1998: 37-60.

34. Hogbin 1932.

35. Hogbin to Elkin, 15 August 1933, HP. (By the mid-1940s, Hogbin argued that colonised peoples in Melanesia, including the Australian-controlled League of Nations Mandate of New Guinea and the Australian Territory of Papua, should have self-government and be responsible for their own affairs.)

36. R Berndt, 1983-84: 161-175.

37. Fortune to JHP Murray, 22 April 1928. National Archives of Australia (NAA) A518/1, A806/ $1 / 5$. 
anthropologists should have been advocates or engaged in adversarial acts but it does raise a moral dilemma: how did anthropologists understand relations on the colonial frontier, their place in these relations, and their responsibilities toward the well being of their 'informants' ? ${ }^{38}$

The foregoing discussion raises a number of questions about the role and influence of anthropologists, individually and collectively: were anthropologists, even if they wanted to, able to modify Australian Commonwealth and State government policy and practice? Was anthropology and its scholarly production influenced by the demands of governments, or were the processes of knowledge production and governance intertwined so that they only occasionally came into open conflict? Ethnographic texts tended to elide the social and political reality of their subjects - Aboriginal people - and revealed anthropology's interest in the depiction of an idealised, integrated 'traditional' Indigenous culture. Did this silence about the interaction between settlers, government agents, missionaries and Indigenous people mean that anthropologists were not able to express their conscious political position, or was it because they had little interest in such matters? Was recording and elucidating the cultural domain of Aboriginal people part of a progressive and effective politics at a time when Aboriginal people were considered to be on the way to extinction, both culturally and biologically? ${ }^{39}$ What was the result of maintaining neutrality about the relations between settlers and Aboriginal people? In the light of Piddington's experience, could 'silence' about such matters be seen as a career choice? On the other hand, because of their special relationship with Aboriginal people, did anthropologists feel a special responsibility toward them? These questions cannot be answered outside the historical domain and much work still needs to be done to understand the politics of anthropology and the ethnographic heritage of the pre-war period. This paper makes some inroads into these complex issues but I do not claim to be able to answer them all. In this paper I concentrate on the multiplex relationships that existed between the anthropologist and the gatekeepers (governments, missionaries, pastoralists and settlers) to the field and these relationships in the field; the relationship between government agents and missionaries, between government and the funding body, and between missionaries and the academic supervisor, who usually represented the funding body; the relationship between local missionaries and their supervisory missionary, between anthropologists and their academic supervisors and the funding body. All these relationships existed, to a lesser or greater degree, in the case of Phyllis Kaberry. ${ }^{40}$

\section{The Kimberley as a site for anthropological research}

The Kimberley in northwest Western Australia was opened to sheep and cattle in the 1880s. It was a particularly brutal and violent period: 'hundreds of [Aboriginal] men, women and children were shot' ${ }^{41}$ In 1926, the year before the anthropologist AP Elkin

38. Gray 2001b: 27-39.

39. James 1973.

40. I have discussed some of these matters in greater detail than here in my papers on Kaberry's predecessor, Ralph Piddington, who worked at La Grange, south of Broome, and surrounding areas in northwest Western Australia, from March to September 1930 and June to December 1931. See Gray 1994; 1997(b): 123-142.

41. Quoted in Biskup 1973: 20. 
first did fieldwork in the northwest, a massacre occurred at Onmalerneri, near Forrest River Mission, which was recalled by some of Phyllis Kaberry's informants in $1934 .{ }^{42}$ In many instances Aboriginal people had been forcibly removed from their country and resettled on mission settlements or government reserves. Several government reserves such as Moola Bulla Native Settlement and Violet Valley Feeding Depot had been created in response to pastoralists' concerns about the killing of cattle on their stations by Aboriginal people. Moola Bulla, for instance, had a twofold aim: its primary purpose was to act as a buffer between the 'semi-nomadic aborigines' and the marginal pastoral regions; its subsidiary purpose was to 'civilise' the local Aboriginal people. The Chief Protector of Aborigines in Western Australia, AO Neville, argued that stations such as Moola Bulla enabled the gradual transition towards civilisation. ${ }^{43}$

The area between the Kimberley, Arnhem Land in the Northern Territory and Cape York in Northern Queensland was chosen by Radcliffe-Brown as the location for intensive anthropological research. Despite the dramatic effects of European settlement which had led to the dispossession, displacement, resettlement and in some places the almost total disappearance of Aboriginal people, with consequent cultural and social destruction, in this area Radcliffe-Brown considered Aboriginal people to be as 'yet comparatively uninfluenced by contact with civilisation'. In his opinion there were sufficient old people, particularly old men - over fifty-five years of age - who remembered life before contact with Europeans and it was therefore one of the last places where Aboriginal people could be described and so captured for scientific posterity. ${ }^{44}$ Arnhem Land was likewise an area where 'true' Aborigines - to use an expression used by the anthropologist Marie Reay ${ }^{45}$ - untouched by settlement, could be found. For example Donald Thomson, ignoring Lloyd Warner's earlier work in Arnhem Land, described Arnhem Land as 'the last great tract of country in Australia to be explored. Up to 1935 almost no information was available about the area and its native inhabitants. No anthropological survey had been made and the natives had never been brought under control'. 46

Radcliffe-Brown sent Elkin, an ordained Anglican priest who had recently completed his Doctor of Philosophy with the diffusionists WJ Perry and Elliot Smith at the University of London, to the Kimberley in 1927-28 under the auspices of the Australian National Research Council to conduct a survey of those still extant tribes, recover what information he could about their social organisation, and make suggestions for future research. ${ }^{47} \mathrm{AO}$ Neville was supportive of the anthropological enterprise, believing that science could assist government in the management and development of Aboriginal

42. Biskup 1973: 84-89; Kaberry Notebooks, 1/2, MS 739, Australian Institute of Aboriginal and Torres Strait Islander Studies (AIATSIS), Canberra.

43. Biskup 1973: 96-116; Neville to Kaberry, 6 December 1935. Western Australia State Archives (WASA), ACC 993, 178/38. Unless otherwise indicated all correspondence cited is from this file.

44. The call 'before it is too late' has weaved its way through Australian anthropology for the better part of the twentieth century.

45. Personal communication, February 1993.

46. Thomson 1948-49; Warner 1937. Warner appears to have stayed near Millingimbi and not ventured far into the 'bush'.

47. Gray 1997a: 27-46. 
people, as well as adding to the 'knowledge of mankind': he was 'interested in anything that will lead to a further knowledge of the blacks' ${ }^{48}$ At the same time, Radcliffe-Brown placed Lloyd Warner in Arnhem Land and Ursula McConnel in Cape York. A decade later Elkin, by then Professor of Anthropology at the University of Sydney, took the view that there were 'still almost untouched fields' and in 'some instances the native order of life is not yet fundamentally altered' in the eastern parts of northwest Western Australia, particularly the eastern Kimberley. There was an opportunity for research to be done 'not so much of the study of the changes which are in progress, as of the original culture, of which some, and occasionally much, remains' ${ }^{49}$

Anthropological researchers were dependent on the various agents of government; Neville, for example, advised Elkin and other researchers where Aboriginal people lived and could be found in Western Australia. He warned Elkin that the east Kimberley was 'an entirely unsettled district, except for the two Mission Stations and the Government Station at Avon Valley, and you are bound to meet with many difficulties'. He therefore advised Elkin to 'have another white man with you, besides one or two trustworthy natives'. Neville explained that Aboriginal people 'have unfortunately had a rather bad experience in their contact with whites, and are said to be treacherous. They are certainly very shy, and may be difficult to get in touch with' ${ }^{50}$ Elkin, once in the east Kimberley, wrote to Radcliffe-Brown that Neville 'doesn't realise the change that has been wrought in the twenty years ... The missionaries can walk anywhere in safety' ${ }^{51}$ When Elkin discussed future field sites with Radcliffe-Brown he advised that, although Drysdale River was an 'important centre for intense study' he did not think it and Forrest River were 'suitable centre[s] ... even for work amongst the women', nor was it 'advisable to send a woman for research into the Kimberlies (sic)' ${ }^{52}$

In 1930 Ralph Piddington, who had recently completed his MA in anthropology and psychology at the University of Sydney, began fieldwork at La Grange Government Feeding Station, near Broome. He was eager to establish a sound working relationship with Neville, and, like Elkin and Porteus, was appreciative of the support Neville and his departmental officers provided him and his wife ${ }^{53}$ in the field. He visited Neville on the way to La Grange, and on his return six months later, when he discussed matters concerning the treatment and conditions of Aboriginal people at La Grange and the behaviour of the white employers of Aboriginal labour. Neville, grateful for Piddington's tact and discretion, promised to inquire into his allegations. Piddington returned to La Grange in August 1931 to find nothing had changed. ${ }^{54}$ It was after his return to Sydney in January 1932 that Piddington was interviewed by the Sydney weekly, The World, and cited specific instances of gross racial discrimination and

48. Kaberry to Neville, 4 May 1935.

49. Elkin 1939: 18.

50. Neville to Elkin, 27 August 1927, WASA, ACC 993, 365/27.

51. Elkin to Radcliffe-Brown, 4 February 1928. EP, 158/4/1/39.

52. Elkin to Radcliffe-Brown, 31 May 1928; Elkin to Radcliffe-Brown, 4 February 1928. EP, 158/4/ 1/39. Cf Marcus 2001.

53. Piddington and Piddington 1932: 342. This was Piddington's first wife. His second wife, an actress, was also called Marjorie.

54. Piddington and Piddington 1932: 343. During the second visit he was accompanied by the American linguist Gerhardt Laves. 
urged, along with other humanitarians, a government inquiry into the conditions of Aboriginal people across northern Australia. This created a furore in Western Australia. Neville in particular took particular umbrage at such allegations. Piddington's were not the only allegations of mistreatment of Aboriginal people in Western Australia: these concerns led to a Royal Commission 'Appointed To Investigate, Report, And Advise Upon Matters In Relation To The Condition And Treatment Of Aborigines'. ${ }^{55}$ Anthropological research in Western Australia was suspended as a result of Piddington's action. ${ }^{56}$

\section{Not the type to cause any complications}

In March 1934 Neville received a letter from Elkin stating that he had a 'girl student who has done a brilliant course and has just received her MA degree, who should now do some field work'. Kaberry was the first woman to graduate with an MA (first class honours) in Anthropology. Her forthcoming trip to the Kimberley was breathlessly reported in the Sydney Morning Herald: 'Miss Kaberry is only 23 years of age, is slight of build and less than $5 \mathrm{ft}$ 3ins in height but possessed of great courage and is supremely confident of success in her undertaking. She will work entirely by herself' ${ }^{57}$

Elkin assured Neville that Kaberry 'is not the type to cause any complications [and] will not cause you any problems such as were unfortunately caused by a previous worker'. He wanted her 'to make a special study of aboriginal women, inquiring into their beliefs, their view of aboriginal religion and the like, and also study the development of the female from birth to death'. A young female anthropologist investigating Aboriginal women was the least threatening enterprise possible to enable the return of anthropological research in Western Australia. And was making peace and building bridges not a woman's special domain? Elkin, who had a good sense of Neville, thus extolled the virtues of his 'girl student' and the chosen research focus, and opened up the problem of a suitable field site as a space for Neville to assert himself. He had considered Mount Margaret, Munja or Forrest River. 'The first may not be very satisfactory ... [Nevertheless] this is the place where I should like a good woman worker to go'. ${ }^{58}$ Neville expressed some reservation, ${ }^{59}$ so that Elkin dismissed the idea of Kaberry working at Mount Margaret; instead he decided to send her to Forrest River, controlled by the Australian Board of Missions (having obtained permission from the Archbishop of Perth), and, if she had time, to Moola Bulla. ${ }^{60}$ Kaberry spent almost six months at Forrest River, leaving at the end of November 1934 because both Elkin and Neville considered the wet season to be too harsh and debilitating for a white woman. Her work at Forrest River and in the east Kimberley was uneventful: Elkin reported that she was getting on well ${ }^{61}$ and 'Mr [Michael] Durack has given her a welcome to his [cattle] sta-

55. For a brief summary and discussion on the Moseley Royal Commission (1934) see Biskup 1973: 167-169; Jacobs 1990: 213-217, 220-240; Paisley 2000: 118-131.

56. See Paisley 2000: 118-131; Gray 1994: 217-245; 1997(b): 113-147.

57. Sydney Morning Herald, 17 May 1935. The University of Sydney did not offer a PhD in Anthropology until 1955; the first Australian university to offer a PhD in Anthropology was the Australian National University, established in 1946 as a research university.

58. Elkin to Neville, 22 March 1934, WASA, ACC 653, 120/25.

59. Neville to Elkin, 9 April 1934, WASA, ACC 653, 120/25.

60. Elkin to Neville, 18 April 1934, WASA, ACC 653, 120/25. 
tions'. ${ }^{62}$ Elkin was pleased with the results of her work: she made a 'real contribution through her study of the women and their point of view' ${ }^{63}$

Kaberry returned to Western Australia in March 1935. Elkin was still keen for her to work on a mission, settlement or station, along the edge of the settlement north of Laverton, where she could 'observe women in their ordinary native setting' ${ }^{64}$ Elkin remarked that

women who go out to do anthropological work amongst the Aborigines should work consistently through the native women, not to find out what a male worker can better ascertain through the men, but to get a real understanding of childhood, motherhood, the family, and the women's place in society. [Aboriginal] men spend most of their lives either directly in ritual and ceremony or else under its influence - their life is like an iceberg, nine tenths hidden, secret ... But the women's life, and that part of the men's life which is passed with the women and children, reveal the essential and natural humanity of the aborigines. ${ }^{65}$

Elkin had written to Rod Schenk, the mission superintendent of Mount Margaret, asking 'whether he would risk another anthropologist, after me!' Elkin had briefly visited Mount Margaret at the end of 1930; Mary Bennett, a mission worker, 'outspoken controversialist', and 'also one of the outstanding [A]boriginal educators in Australia', had publicly accused Elkin of having deliberately encouraged 'sorcery practices' during his stay. ${ }^{66}$ Kaberry's attempt to stay at Mount Margaret brought forth Schenk's animosity toward anthropologists, ${ }^{67}$ especially Elkin. Schenk had not forgiven what he understood to be Elkin's deception of not declaring that 'he was an Anglican clergyman while he was here': Elkin had denied his Christian duty. He accused Elkin not only of 'leading our [Christian] men into ceremonies quite contrary to the Scriptures he was supposed to teach' but encouraging 'a revival amongst the natives of most degrading practices ... unseemly ceremonies that even the middle-aged men had not seen'.68 Elkin's intervention had awoken ceremonial life which had lain dormant with some of the older men. Schenk, who strove for a speedy breakdown of practically all Aboriginal customs and traditions, had had years of hard work destroyed. ${ }^{69}$

Schenk was not in the mood for anthropologists, whom he considered wanted only to 'keep these souls just for museum specimens' ${ }^{\prime 70}$ He told Elkin he 'has so many white people, visitors and missionaries on his station that he doesn't want any more'. ${ }^{71}$

61. She wrote to him regularly, see various EP, $247 / 631$.

62. Elkin to Neville, 2 October 1934. The Durack family, led by Patrick Durack, settled in the Kimberley in the 1880s and established a string of cattle stations. (See Durack 1959).

63. Elkin to Neville, 7 March 1935

64. Elkin to Neville, 7 March 1935.

65. Elkin 1935b: 197

66. Elkin to Radcliffe-Brown 6 December 1930; Elkin to Firth 1 August 1931, EP, 158/4/1/40; Biskup 1973: 132. Mary Bennett had been an active and persistent critic of the treatment and conditions of Aboriginal people, especially in Western Australia, and had taken her campaign to Britain. See Paisley 2000.

67. cf Duckham, 2000: 48-51.

68. Schenk to Elkin, 4 April 1934, EP, 167/4/2/52

69. Schenk to Elkin, 9 May 1935, EP, 167/4/2/52.

70. Schenk to Neville, WASA, 219/1932.

71. Elkin to Neville, 23 April 1935. 
Neville then suggested the Warburton Ranges about 250 miles east of Laverton, 'if Miss Kaberry is game to undertake travelling per camel, etc it would certainly be a useful experience for her amongst the people out there if it is these people she wishes to meet. ... There are many natives around this district, and attempts to reach them would, I feel, be justified from an ethnological point of view' ${ }^{72}$

Schenk emphasised to Elkin and Neville that Kaberry was not welcome on the Mount Margaret mission compound, and he was sure that the missionaries at Mount Warburton would not co-operate either. ${ }^{73}$ Nevertheless, Kaberry decided to visit Mount Margaret on the way to Laverton, 'seeing if [she] could reason with Schenk' ${ }^{74}$ She wrote to Elkin soon after telling him that there was 'no hope for Mt Margaret ... Schenk was abominably rude. He lost his temper before I could say anything, abused you, [Frederick] Wood Jones and all anthropologists, and said if I camped he'd do anything to get me shifted. The man was malevolent. Mrs [Mary] Bennett was there and had seen that paragraph about me in the West Australian. She was antagonistic' ${ }^{75}$ The missionaries at Warburton however were willing for Kaberry to go there but 'illness prevented them returning immediately [to the mission station] ... [hence] the Warburtons must be considered a doubtful part of my programme ... At the moment I've reached a deadlock and haven't recovered from my encounter with Schenk. However I expect something of value will emerge eventually' ${ }^{76}$

At Laverton Kaberry found the mission intrusive: she noted that 'every Black (more or less) ... asked me whether I prayed' ${ }^{77}$ In a letter to Mary Durack, with whom she had struck up a friendship the previous year, she described the situation:

Laverton was pretty ghastly from an anthropologist's point of view. The natives were very sophisticated, were camped about $2 \frac{1}{2}$ miles away and spoke scarcely any English, any who had been contaminated by the mission atmosphere took upon themselves to inquire after your spiritual welfare and continually demand whether I prayed or not!!! After two weeks I reached a zero of depression. ${ }^{78}$

Kaberry decided that she had to leave Laverton. 'Last year', she informed FI Bray, Neville's deputy, 'Mr Neville was rather keen for me to visit Moola Bulla, but I was unable to do so. If the Wiluna district is not good, I may consider a visit to the Kimberleys'. ${ }^{79}$ Bray replied that he hoped Kaberry was not 'unduly worried by the cold atmosphere' at Laverton and advised her 'to communicate with [Neville] promptly and I am sure your difficulties will disappear just as quickly' ${ }^{80}$ Kaberry also wrote to Elkin explaining her position and her intention to move to Moola Bulla. ${ }^{81}$ But she couldn't

72. Neville to Elkin, 20 March 1935.

73. Elkin to Neville, 23 April 1935; Neville to Wade (United Aborigines' Mission), 10 May 1935; Biskup1973: 132-134.

74. Kaberry to Neville, 4 May 1935; Kaberry to Neville, 6 May 1935. For a contemporary discussion about the danger of anthropologists see Cowlishaw 1999.

75. Kaberry to Elkin, 9 May 1935, EP, 247/ 631

76. Kaberry to Elkin, 9 May 1935, EP, 247/ 631.

77. Notebook (1/6), 21 May 1935, AIATSIS, MS 739.

78. Kaberry to Mary Durack, 16 June 1935, Durack Papers (DP), Berndt Museum, University of Western Australia.

79. Kaberry to Bray, 12 May 1935.

80. Bray to Kaberry, 15 May 1935.

81. Kaberry to Elkin, 12 May 1935, EP, 247/631 
wait for a reply, and the following day wired Bray: 'May I stay Moola Bulla sail 29th urgent wire Laverton'. ${ }^{82}$ Kaberry nevertheless considered that the difficulties she encountered at Laverton were 'largely my own fault' ${ }^{83}$

\section{Then they come and undo our work}

Soon after Kaberry's departure Schenk wrote to Neville that Elkin had indicated he would use Neville as a way to 'force a way for Miss Kaberry' to work at Mount Margaret. ${ }^{84}$ Kaberry, too, had implied that 'you [Neville] gave her authority to dwell here. I had reason to think that she did not keep to the truth. Perhaps I know more about Miss Kaberry than you do and I know that she is not a person to stay here and no one else with the same corrupt views on Christian teaching. We would not try to force our way on to them' [as contrasted with anthropologists]. ${ }^{85}$ He was irate that Kaberry should come

here pretending to be a Christian and yet like Dr Elkin want to encourage the natives into all kinds of superstitious rites in opposition to our teaching is lack of principle and is undoing the work of those who befriend the natives. ... The natives say that at Laverton most of Miss Kaberry's dealings are with the old men, yet she says she came to study the women's side. Moreover, they tell us that Miss Kaberry tells the natives that she is a 'Happy Land' [Christian] lady, yet we know different.

Schenk accused her of trying to 'induce the natives to stage one of their devil devil corroborees for her'. ${ }^{86} \mathrm{He}$ reiterated the suggestion that Kaberry was not a fit person: 'We have confidential advice which we cannot reveal' ${ }^{87}$

The suggestion of improper behaviour by Kaberry was cause for concern. While on the surface Neville supported Kaberry's work - he described her as a 'nice quiet girl' - he was always conscious of the possibility that she could cause trouble with missionaries and other settlers. Bray's reply was immediate: 'I shall be pleased if you will kindly write to me more fully of your knowledge of Miss Kaberry. Miss Kaberry is going to Moola Bulla to study the natives of the North, and if you can furnish me with facts in support of your general statement respecting her, it may appear that she is not a satisfactory person to be entrusted with the credentials of this Department' ${ }^{88}$ Schenk did not reply.

Neville, on returning from a trip to the northwest, read through the correspondence and followed up on the matters of concern. He thought it regrettable that Schenk felt impelled to adopt the attitude he had, thereby putting the Anthropological Committee of the Australian National Research Council and the department to additional

82. Kaberry stayed at Laverton from 10-27 May 1935. Dates from field note books (AIATSIS, MS 739); Kaberry to Bray, 16 May 1935; Bray to Neville, 16 May 1935; Neville to Bray, 18 May 1935; Bray to Kaberry, 20 May 1935; Kaberry to Bray, 21 May 1935.

83. Kaberry to Elkin, 16 May 1935, EP, 247/ 631; Kaberry to Elkin, 22 March 1936, EP, 8/1/1/85.

84. For a short description of the philosophy underlying Mt Margaret Mission see Biskup 1973: 131-133.

85. Schenk to Neville, 18 May 1935.

86. Schenk to Neville, 29 July 1935.

87. Schenk to Bray, 10 June 1935.

88. Bray to Schenk, 24 May 1935; Bray to Schenk, 21 June 1935. 
expense and Miss Kaberry to considerable inconvenience and additional travelling. $\mathrm{He}$ desired in future 'no contretemps of this nature'. Rather, he told Schenk, the 'Department, the Missionary and the Anthropologist should work hand in hand. There is certainly a place for each, and your adoption of this view would I feel sure tend towards avoidance of any untoward incidents of the nature referred to and be highly appreciated by all those workers in the cause, who whether they think on the same lines as you or not, are out to preserve the interests of the aborigines generally.' He assured Schenk that no worker under the auspices of ANRC was 'permitted to work in Western Australia without my full knowledge and sanction and I was satisfied of Miss Kaberry's bona fides before suggesting that you might be in a position to help her at Mount Margaret'. He concluded by warning Schenk that his appointment as a Protector of Aborigines was subject to revision and reminding him that as 'a Protector we look for the fullest possible co-operation with the Department' ${ }^{89}$

Schenk did not take kindly to the reprimand and set out an explication of his actions. Schenk was 'sorry to read ... that my contact with the natives as a missionary depended upon my appointment as a protector'.${ }^{90}$ He declared that anthropological work was 'wholly opposed to Scripture teaching' and he could provide 'many instances ... to prove this'. Anthropologists were not, in his view, agents of modernisation: rather it was the mission who turned people away from animism to the uplift of Christianity. The work of the mission 'turn[s] the natives to Christ without whom there will be no forgiveness. We want souls saved from hell'. Anthropologists pulled people back by attempting to get them to re-invigorate their past by performing ceremonies which were the antithesis of Christian teaching. Anthropologists undermined the work of the mission. 'They are not even satisfied with asking the natives things, they want to see them staged, they drag them back to hell'. After Elkin's visit, Schenk wrote, 'we were plunged into one of the greatest blood feuds in the district'. It was 'one of our most sorrowful periods of natives going back to drinking blood after Dr Elkin's visit' (Schenk's emphasis). ${ }^{91}$

Neville concluded that Kaberry had not behaved in a way detrimental to the ANRC nor criticised the WA administration of Aboriginal affairs. He told his Minister there was nothing more to be said 'as Miss Kaberry is elsewhere, and it is hard to reason with a man of Mr Schenk's type'. ${ }^{92}$ But Neville did not let the matter rest there. Margaret Morgan, Schenk's daughter, argues that the action over Kaberry led to an increasing tension and eventual rupture in relations between the two men. It was, she said, the beginning of the struggle and conflict between Schenk and Neville. ${ }^{93}$ In her biography of Neville, Pat Jacobs declared that it 'caused a further rift in the relationship of Neville and Schenk'. ${ }^{94}$ From the mid-1930s Neville made constant attempts to undermine the importance of the mission: 'instead of helping, rations were reduced, medicines were

89. Neville to Schenk, 19 July 1935; Memo, 22 July 1935; Elkin to Neville, 23 April 1935.

90. Schenk to Neville, 26 July 1935.

91. Schenk to Neville, 29 July 1935.

92. Neville to Minister, 5 August 1935. By April 1938 Peter Biskup states that 'relations between the department and the [United Aborigines Mission] had reached breaking point', Biskup 1973: 139.

93. Morgan 1986: 197.

94. Jacobs 1990: 249. 
refused, obstacles were put in the way of Christian marriages, escort fees accorded to others were refused to missionaries, and no financial help of any kind came their way' 95

\section{I started work in earnest}

Kaberry arrived at Moola Bulla on 11 June 1935, having regained her enthusiasm for work: she was happy to be back in the Kimberley. She intended to put in three months at Moola Bulla, then go north to Violet Valley and 'then do some camping ... The Blacks remain around the station till the "wet" season, when according to the head stockman here, they have their corroborees, and initiation ceremonies'; the 'Blacks are very friendly, and having overcome their preliminary shyness, have no hesitation in discussing their customs with me' $^{\prime}{ }^{96}$

In the report on her fieldwork she thanked Elkin for the 'loan of his unpublished notes [that] had provided an invaluable basis for [her] fieldwork at Forrest River' ${ }^{97}$ She corresponded with Elkin, remarking on matters which were of particular interest to him. ${ }^{98}$ She pointed out differences between Elkin's observations and her own, especially on kinship, marriage rules and 'spirit conception'. Elkin was particularly interested in conception beliefs, 'magic men' and religious life. They shared informants: Kaberry referred not only to Whisky, ${ }^{99}$ who 'would be most helpful as he speaks excellent English', 100 but to Aladoa, whom she met at Forrest River in 1934 and who was now at Moola Bulla: 'He should prove useful while I am here'. ${ }^{101}$ Her main women informants would most likely have been unknown to Elkin.

Kaberry conducted her field work by travelling from station to station and once there she was largely constrained by the geographical boundaries of the station. She frequently discussed, in her correspondence with Elkin (and to a lesser degree with Neville), her travel plans and movement, what she anticipated finding, or an event ceremony or such like that was due to be performed - that encouraged her to move. There were considerations such as being 'handy to supplies', obtaining suitable transport, locating large groups of Aboriginal people for ceremonies - initiation, circumcision, sub-incision and such like, white people (pastoralists and missionaries) favourable to her enterprise, and the weather, especially during the 'wet' season. An unhelpful station manager or manager's wife could make work difficult. ${ }^{102}$

95. Morgan 1986: 128-263; Jacobs 1990: 224, 249, 260-261; WASA, ACC 953, 487/1937, various.

96. Kaberry to Elkin, 22 June 1935, EP, 8/1/1/85; Kaberry to Mary Durack, 16 June 1935, Durack Papers, Berndt Museum, University of Western Australia.

97. Kaberry 1935: 408 .

98. Kaberry to Elkin, 11 August 1935, EP, 8/1/1/85. Radcliffe-Brown conducted a voluminous correspondence with his fieldworkers in a manner similar to that between Elkin and his fieldworkers.

99. Kaberry's reference to Whisky made Elkin 'anxious to return to the East Kimberley, for he was a very interesting blackfellow'. Elkin to Neville, 8 August 1935 . .

100. Kaberry's language skills are difficult to assess. The anthropologists Nancy Williams and Sandy Toussaint both argue for her language competency. Kaberry, in Aboriginal Woman 1939: 9, stated she 'had no time to master languages' although she provides clues in her correspondence that she could speak 'pidgin'.

101. Kaberry to Elkin, 22 June 1935, EP, 8/1/1/85; Elkin to Neville, 8 August 1935; see also Kaberry to Elkin, 22 September 1934, EP, 8/1/1/85. 
When Kaberry did have the opportunity to move away from the compound she found a different environment:

One of the more intangible results ... was that I gained some insight into their daily life and saw them as human beings. The last remark needs some explanation. I don't mean that I had previously thought of them as children or as subhuman. But 'interviewing' for 5 hours every day at the mission, there is the danger of regarding them solely as repositories of anthropological information, particularly in the case of one, who like myself has never come into contact with Blacks, or any natives before. The method, though unavoidable, has its artificial aspect in that one hears about their life, but sees very little of it. So that while I did not fill notebooks, I do honestly think the 18 days were valuable ones; were worthwhile. ${ }^{103}$

She told Mary Durack that:

so anthropological have I become that my surroundings no longer seem incongruous; in short I am as adaptable as the chameleon and as nomadic as the Black brethren. Nothing exciting has happened - I bathe in the rockhole with the leeches, collect small ticks, hunt cockroaches and spiders, and I drink water the colour of tea. Apart from that I pursue Blacks like a sleuth ... snaffle genealogies; gossip with the women - and am a picker up of unconsidered trifles (remarks) from which I deduce shattering theories and conclusions. At night I sit with the women and watch corroborees, but so far have not joined in the chanting. These Bks painted with red ochre and white paint seem to have become impregnated with the colour of their surroundings - to vitalise it. ${ }^{104}$

Kaberry considered that:

[her] own make up is peculiarly suited to fieldwork. Fundamentally I am of course feminine, and I don't go round looking as though I had a spanner in my hip pocket. But I have the faculty of being able, as it were, to put my sex into neutral gear and conduct relations on that basis in the majority of instances. Perhaps it is a bit abnormal, but when I meet men its only occasionally I am aware of them physically. My first reaction (as a rule) is to them as individuals - persons - rather than as men, and the same applies to women. I think the same is true of my relations with natives: I react to them first as individuals; only secondarily as people of a different culture and environment. Anyway to come back to the point. Even if the attitude did not come naturally to me, it would be essential, since so often in the field I am the only European woman. I have it both ways: that is, I am treated as a woman but there are no emotional entanglements to upset myself and, more importantly, my work. ${ }^{105}$

102. Kaberry to Elkin, 22 September 1934, EP, 8/1/1/85; Kaberry to Mary Durack, 3 November 1935; Kaberry to Durack, 16 June 1935, DP; Kaberry to Neville, 27 November 1935; McBeath to Neville, 26 November 1935; Kaberry to Elkin, 11 August 1935; Kaberry to Elkin 22 March 1936, EP: 8/1/1/85. Ursula McConnel in North Queensland commented that there were advantages away from the station: 'living in the vicinity of the missions means a good deal of expense ... men in the vicinity of the mission expect wage and rations and tobacco for daily information ... In the bush one does not have to give either rations or money just presents and tobacco'. McConnel to ANRC, 15 August 1934, ANL, MS 482, folder 834.

103. Kaberry to Elkin, 22 September 1934, EP, 8/1/1/85.

104. Kaberry to Mary Durack, 3 November 1935, DP. See Kaberry's poem, 'North Kimberley', in Toussaint 1999: 25-26. 
Catherine Berndt, whose thesis Kaberry had examined, suggested that not only did Mary Durack and her sister Elizabeth, who were 'sympathetic to Aboriginal interests', provide personal support which gave Kaberry 'the emotional support she needed', but they also 'facilitated Kaberry's travels and contacts with Aboriginal people throughout the region, as well as with station owners and managers who were unenthusiastic or even hostile about research' although Kaberry makes no mention of such hostility. ${ }^{106}$ This underestimates Kaberry's fierce independence, her determination and her ability to stand the isolation and demands of field work, and possibly overstates the importance of the role of the Durack sisters as gatekeepers - this was the role of their father ${ }^{107}$ - although Kaberry's friendship with the Durack sisters continued until her death in 1977.

\section{It has opened my eyes to the value of such a station}

Kaberry commented on the effects of invasion and settlement on Aboriginal social and cultural life. She thought it most noticeable in matters to do with marriage, which she believed had led to a breakdown of male authority. She told Elkin of a young man who had married into the alternative subsection ('wrong way'), who was told he would not be able to see significant religious objects (kroga or gunari). '[T]his threat might have been carried out in the old days, but the boy while on a visit to the Margaret station, was shown the kroga by a tribal umbana in return for flour and tobacco' ${ }^{108}$

Other matters where the effects of settlement were noticeable were the 'extinction' of tribal groups or removal of people: '[ $t$ ]wo Blacks have told me, independently, that formerly the Djaba tribe owned the Fitzroy Crossing country and that the Punaba were further back, and the Kunian all around Cox's. Apparently all but one or two of the Djaba are extinct and the language completely gone' ${ }^{109}$ Kaberry added that 'most of the Punaba Blacks deny that they ever had a section system, but admit that they are newcomers to the Crossing and originally belonged to the Leopold Ranges' ${ }^{110}$ There are many other such examples in her field notes and correspondence.

On the other hand Kaberry appeared to take little other interest in the treatment and living conditions of Aboriginal people. There is barely a reference in her correspondence or field notes. While in the field, however, and most likely at Elkin's behest, she kept notes at the back of her notebooks about the living standards of Aboriginal people on the stations she visited. She declared for example that 'station Blacks [are] in a better condition physically than mission Blacks' and '[are] more sophisticated than Mission Blacks'. ${ }^{111}$

Kaberry was impressed by Neville's 'policy of non-interference' and extolled its virtue in an article about Violet Valley for the West Australian. ${ }^{112}$ She told Neville that 'it

\footnotetext{
105. Kaberry to Mary Durack, 29 December 1945 (Cameroons), DP.

106. Catherine Berndt 1988: 169.

107. Kaberry to Mary Durack, 27 January 1939, DP.

108. Kaberry to Elkin, 11 August 1935; also Kaberry to Elkin, 10 August 1935, EP, 8/1/1/85.

109. Kaberry to Elkin, 6 February 1936, EP, 8/1/1/85.

110. Kaberry to Elkin, 20 February 1936, EP, 8/1/1/85.

111. Field note books, AIATSIS, 6/1, MS 739. Elkin was interested in such matters and encouraged his workers to comment on the 'vigour' of Aboriginal people.

112. West Australian, 9 December 1935.
} 
[his policy] has opened my eyes to the value of such a station as Violet Valley. The Blacks regard it as a meeting place during the "wet" season, where they can perform their rites and ceremonies without molestation of any description'. They told her that they knew there would be plenty of food and tobacco, and the police and station owners would not molest their dogs. She told Neville that 'participation in these rites will serve as an antidote for the contempt with which some of the Station Blacks are beginning to regard their own race. The Blacks will have to change eventually, but if changes are to be beneficial they must be based on pride of race; and in the meantime these ceremonies are keeping the race consciousness alive' ${ }^{113}$

She told Elkin that she was sure Neville 'will have no objection to my saying [in her newspaper article] exactly what I think, and if some of the objections made in passing are becoming hackneyed, at least I think that I have presented some of the advantages in a new light. It is the more important since conditions have altered at Violet Valley, and Mosely's [Royal Commissioner] report on it, would now convey, in some respects, a false impression of that station'. ${ }^{114}$ Neville was delighted with her article, reading it with 'much interest' and stating that he 'was pleased that [she] could regard the station so favourably' 115

Kaberry most likely exceeded even Elkin's requirements by writing such a flattering item for the newspaper. There is the possibility that she overstated, rather than misrepresented, the value of a station like Violet Valley. Her assessment can also be seen in a sense as due recompense for Neville's assistance. On the other hand, Kaberry was not adverse to a laudatory compliment. On being asked if she would accept a position as lecturer in the Anthropology department she wrote to Elkin: 'Needless to say I particularly wish to have my first experience of lecturing in your department under your guidance - I look on you as my friend and the prospect of further association with you in your work gives me great pleasure'. ${ }^{116}$ Elkin's support was recognised by Kaberry in somewhat extravagant terms: 'your confidence in me fires a new keenness for my work' $^{117}$ She was fiercely determined to achieve her goals, valued her independence, did not suffer dishonesty easily, and would use whatever means were needed to convince her gatekeepers and patrons of their importance.

Kaberry's support of Violet Valley and Neville's policy on that station does raise a query about her views about Aboriginal policy, the treatment and conditions of Aboriginal people, and the imagined future of Aboriginal people in Western Australia. For example she was aware that women were fearful to talk to her near the manager's house, where she conducted much of her fieldwork: they sought to take her away from the manager's compound so they could talk freely. ${ }^{118}$ On the other hand, she may have taken the view, as expressed by Elkin when he was in the field that he 'was not concerned with Aboriginal policies and problems of contact and clash'. ${ }^{119}$ But such a

\footnotetext{
113. Kaberry to Neville, 27 November 1935; Kaberry to Neville, 4 December 1935; Neville to Kaberry, 6 December 1935.

114. Kaberry to Elkin, 7 January 1936, EP, 8/1/1/85.

115. Neville to Kaberry, 7 January 1936.

116. Kaberry to Elkin 13 December 1939, EP, 247/631.

117. Kaberry to Elkin, 13 December 1939 and various, EP, 247/631.

118. Notebooks, AIATSIS, MS 739.
} 
suggestion is undermined by her praise of Neville and by inference of the Western Australian administration of Aboriginal affairs, whose motto was described as 'uplift by force [and] absorption'; ${ }^{120}$ Pat Jacobs, Neville's biographer, argues convincingly that Neville was a supporter of biological absorption, that is, 'breed them [half-castes] white ${ }^{\prime 21}$ although he held the view that 'the uncivilized natives have a code of their own which is in a way superior to ours but which seems to disintegrate as soon as they get in touch with civilization'. ${ }^{122}$ The problem of 'the half-caste' was a paramount problem for Neville and for the administration of native affairs in Western Australia. ${ }^{123}$

Kaberry commented to Mary Durack, who had herself written several newspaper articles on the future of Aboriginal people, that she considered segregation 'impractical for the majority' of Aboriginal people, although there were 'parts of North Kimberley where they have not found gold, where it's no good for cattle, and where the natives have had little contact' with settlers. 'Probably the same applies to parts of Arnhem Land. They should have a medical patrol officer who speaks the language; perhaps some sort of agric. Station on the outskirts, where food can be grown in case of bad seasons, and perhaps bordering tribes given agricultural instruction. But that wd. only cover a few thousands'. For the rest she was

against segregation. Their old lands are gone; they've acquired tastes for flour and tobacco; but what openings are there? You are not going to get past the colour bar for a long time, so that clerical jobs, and that is, education in the three RS seems a waste of time at present. There are parts of West Kimberley, north of Derby, where you cd. go for agriculture, sandalwood, probably other things. And I'm all for agricultural training. Once they became economic producers in our own system it might convince people that they are not unintelligent: that they can have their place in the nation. The point is that the Govt. won't cede that the land cd. be made fertile. ... I don't see how the cattle stations can absorb them, nor pearling. At the moment it wd. be fatal to bring them south. Glad you took up the point about their "improvidence": I entirely agree with you there. I once referred to their increase sites as spiritual storehouses, and they are. By performing the ceremony they believe they insure for the future, and it's about all they can do till they have the agric. training'. 124

Neville 'liked Kaberry and had gone out of his way to assist her'. He not only anticipated but also looked forward to her visit when she returned to Perth from the field. So when he, 'heard that she passed through Perth but I did not see her ... after all that has been done for her' he was disappointed. ${ }^{125}$ Kaberry indicated she would make an attempt to see Neville on her way to England (where she was enrolled at London University for a Doctor of Philosophy) when the boat stopped at Fremantle, but he noted on her file, 'did not call' ${ }^{126}$ Why she didn't call on him is difficult to ascertain; we can only speculate. It may have been deliberate or it may have been circumstantial. She

\footnotetext{
119. Elkin 1994: 299.

120. Biskup 1973: 188-189.

121. Jacobs 1986: 15-23.

122. Quoted in Biskup 1973: 122.

123. See Jacobs 1990.

124. Kaberry to Mary Durack, 2 December 1939. DP.

125. Jacobs 1990: 249 .

126. File note, 22 September 1936; Neville to Kaberry, 29 July 1936.
} 
may not have had time to travel to Perth from Fremantle; she may have felt ambivalence toward him especially as she was unlikely to return to Western Australia for fieldwork; she may have secretly disliked him. Whatever the reason, Neville's disappointment only reinforced his feelings that he was not properly recognised by anthropologists.

\section{She made a good impression on Malinowski}

Raymond Firth reported to Elkin from London that he and Audrey Richards were pleased with Kaberry's progress, and he noted that she had 'made a good impression on Malinowski too'.127 Kaberry completed her Doctor of Philosophy - 'The position of women in an Australian Aboriginal society' - within two years, and she returned to Australia in 1939. The same year her book, Aboriginal woman: sacred and profane was published. The anthropologist Marie Reay described it as an 'intensive functional analysis', a 'pioneering study of the social position of women' and, with the exception of a brief survey of women's life in northern South Australia by CP Mountford and Alison Harvey, the only one until 1961 to do so. ${ }^{128}$

In retrospect, the Kimberley research was a brief period in Kaberry's life as an anthropologist. Elkin, who offered her a lecturing position in 1939, wanted her to do more work in northwest Western Australia. She asked Mary Durack if there was any hope of Durack's father allowing her to go to Auvergne, a Durack cattle station, if Elkin insisted that she work in Australia: 'I'll want to do more camping and get out from there more than in 1935-36 and make a study of the language'. ${ }^{129}$ However it was unnecessary as she had 'almost talked E[lkin] round to Melanesia. I'd like to do Auvergene later but as I explained at the moment I am stale on Australian Anthropology and I want the excitement of studying a new native people' ${ }^{130}$

While she kept in contact with family and friends in Australia, Kaberry's life's work as an anthropologist was devoted to Africa. Jeremy Beckett, one of her students, recalls that she 'did not regard this episode [her fieldwork in Australia] with much nostalgia [although] it figured in some of her courses'. ${ }^{131}$ In fact, in some ways she saw Aboriginal anthropology as intellectually limiting internationally and commented that neither the journal Oceania nor Aboriginal ethnography generally had much acceptance or interest from British anthropologists. ${ }^{132}$ Ursula McConnel had made a similar observation some years earlier, when she declared that 'after 8 years of research carried out by numerous field workers in Australia ... Everywhere the lack of publication by Australian field workers is commented on' ${ }^{133}$

In telling the story of the politics surrounding Kaberry's fieldwork in the Kimberley one cannot help asking: was the control exercised by Neville and the tactful care

127. Firth to Elkin, 19 March 1937, EP, 160/4/1/78.

128. Reay 1963: 322.

129. Kaberry to Mary Durack, 27 January 1939, DP.

130. Kaberry to Mary Durack, 14 February 1939, DP.

131. Beckett 2001: 85.

132. See also R Berndt 1967: 252-256. Berndt was critical of the lack of interest in Aboriginal Australian Anthropology by British anthropologists, and secondly their extensive use of material from the end of the 19th century and the early 20th century.

133. McConnel to David Rivett, April 1935, ANL, MS 482, folder 834. 
asked for by Elkin too demanding for such an independent and determined person such as Phyllis Kaberry? The Australian field, Marie Reay asserts, 'was difficult' and 'unrewarding for younger anthropologists'. She thought 'it was no accident that Phyllis Kaberry did her study of Aboriginal women under the direction of Professor Elkin, who was extremely anxious that such studies should be done, and then deserted the Australian field altogether' ${ }^{134}$ Kaberry's reluctance to see Neville, and her resolve to prefer an insecure future in London over the opportunities - research and a lectureship - offered by Elkin in Australia, seem to indicate that it was. ${ }^{135}$ Fieldwork in the Kimberley and dealing with Neville were truly an initiation for the practitioners of the discipline of Piddington's and Kaberry's generation. It was, I suggest, the politics of anthropology in Australia, as much as the greater freedom and opportunities elsewhere, that led to Kaberry's departure from Sydney, first to the United States of America then to London and the field in Africa.

\section{Conclusion}

I began this paper with three main questions: firstly, could anthropology/ anthropologists modify official government policy and practice; secondly, was anthropology influenced by government policy and practice; and finally, if anthropologists were 'silent' about the social and political reality of Aboriginal conditions, did this represent a lack of interest in analysing relations between settlers and Aboriginal people, or did this reflect a lack of political awareness or an unwillingness to be involved in political issues? I have examined these questions in terms of the multiplex relations found between settlers, pastoralists, government agents, missionaries and the anthropologist, in the case of Phyllis Kaberry.

From a review of Kaberry's field work it is apparent that she presented to the reader a portrait of Aboriginal life which largely disregarded contemporary life on reserves, missions and pastoral stations. As Christine Cheater has pointed out, Kaberry recognised the apparent dislocation of tribal boundaries to the extent that she grouped 'people according to the station they worked on', which enabled her to keep track of their movements. ${ }^{136}$ It was not that Kaberry denied that Aboriginal people in the Kimberley were living in a settled area - she noted that 'the natives have been in contact with the whites for over forty years ${ }^{137}$ - but rather that this contact was not analysed as having any serious effect on the way Aboriginal people lived, where they lived, their ceremonies and such like: Aboriginal life was presented as 'timeless'. ${ }^{138}$ More importantly for my argument, she elided the colonial relations on the frontier, thus seemingly suppressing the consequences of the violent history of settlement, particularly that of the Duracks when they established a string of cattle stations in the last twenty years of the 19th century. The anthropologist Francesca Merlan comments that Kaberry 'did not address questions about the articulation of the particular Aboriginal society she observed (nor, should it be added, its interaction with European pastoralism)' ${ }^{139}$

\footnotetext{
134. Reay 1963: 325-326.

135. Kaberry to Elkin, 5 September 1939, EP, 247/631; also various EP, 8/1/1/85.

136. Cheater 1993: 141.

137. Kaberry 1939:x

138. Kaberry's poem, 'North Kimberley', discusses the timelessness and anthropomorphic nature of the landscape.
} 
It is difficult to imagine that within the space of two or three years after Piddington had been in the Kimberley that there had been a change in relations between Aboriginal people and settlers. Piddington claimed that the abuses at La Grange were typical of the state of affairs in Western Australia generally. It is apparent, for reasons unknown to us, that Kaberry did not see the sorts of abuses witnessed and described by Piddington. Elkin, although blinkered by his 'adventure' in 1927-1928, declared some years later that he had, slowly and 'unconsciously', become aware of the appalling conditions and treatment of Aboriginal people. Was Kaberry's friendship with the Durack sisters in fact a hindrance in writing about what she saw, or was she immune to such suffering, recognising instead the shared humanity of Aboriginal and non-Aboriginal? This latter was after all a purpose of anthropology as stressed by Radcliffe-Brown, Firth and Elkin. Or, having seen what had happened to Piddington, was she well advised by Elkin to remain silent about any abuses of Aboriginal people she may have witnessed?

Kaberry's research did little other than lend support to Neville's administration of Aboriginal affairs through her support of Violet Valley. She appears to have had no impact on policy and practice or on the way Aboriginal people were treated, nor did she attempt to ameliorate their conditions. But neither did Piddington alter the way Aboriginal people were treated or the conditions in which they lived on the cattle stations, feeding stations, or government-run reserves, although his public criticism certainly had an impact on the Western Australian government and its administration of Aboriginal affairs. In the end the findings of anthropology did not lead to a modification of government policy and practice. Piddington commented on the Report of the Royal Commissioner into the 'Conditions and Treatment of Aborigines' which had considered his allegations:

The Report is a comprehensive and carefully balanced summary of the evidence presented to the Commission. But, since there is no doubt of the Commissioner's thoroughness and impartiality, it seems that such evidence has not been adequate to reveal the extent and seriousness of the abuses which, it is admitted, occur in "isolated cases". ... [A]n itinerant Commissioner must necessarily experience difficulty in reaching a true appreciation of the position. ${ }^{140}$

What Kaberry did achieve for Elkin, which was most important from his point of view, was the acceptance of anthropological research after the Piddington debacle. Nonetheless, Raymond Firth, despite Elkin's success, thought Elkin 'went too far in mollifying government sensitivities'. ${ }^{141}$ Neville, notwithstanding his cautious support for anthropological research, was nonetheless wary of anthropologists after his experiences with Piddington, Porteus, and Kaberry, doubting the value of anthropology, and not placing anthropological research as a priority. Faced with continuing anthropological research or with using state funds to support research, he would have preferred that that money be 'added to what we have for Departmental purposes, while the position of the natives is as it is'. ${ }^{142}$ Elkin had hoped to entice Kaberry back to the Kimberley,

\footnotetext{
139. Merlan 1988: 22.

140. Piddington 1936: 196-197. Dorothy Billings, a student of Piddington's in Auckland in the 1950s, told me that Piddington always said, 'As anthropologists we observe, as citizens we take a stand'. Billings to author, 10 January 2002.

141. Firth to author, 20 February 1993, held by the author.

142. Memo to Minister, Neville, 11 May 1933, WASA, ACC 653, 120.
} 
but she wanted new fields and new opportunities, and on her return from London went to work in New Guinea. He did however manage to place the linguist Arthur Capell in the northwest at the end of the 1930s.

Elkin however made only limited use of Kaberry's research. It provided him with further information on the lives of women and supported his argument that Aboriginal women were not merely chattels, as well as answering queries and thus rounding out his knowledge from his earlier research in the Kimberley. But this information was not used by Elkin in his general text, The Australian Aborigines. How to understand them, published in 1938. Kaberry told Mary Durack that the 'book is good as a general summary but it has nothing about the women and their part in the life of the tribe'. ${ }^{143}$ Elkin was unable use Kaberry's work as part of a larger discourse about culture contact and modernity - he was still unsure how to 'help them [Aboriginal people] rise culturally' although he recognised that 'our [white Australians'] great need ... is to understand them and the cultural problems which confront both them and ourselves' ${ }^{144}$ Neither did Elkin discuss the outcomes of Kaberry's work with Neville or his successor FI Bray.

Schenk, while only a minor part of this story, maintained his opposition to anthropologists; the United Aborigines' Mission established mission stations at Warburton, Cundelee and Ooldea. All but Ooldea hindered anthropological researchers in some way, and after 1941 Harry Green, the superintendent at Ooldea, also took a similar view to Schenk. For example, after initially welcoming Ronald and Catherine Berndt, he wrote to the Aborigines' Protection Board that he did not want them at Ooldea as they were 'having a very unsettling effect upon the Natives'. Green 'deeply resent[ed] [the Berndts'] persistent questionings into matters which concern their tribal life and Secret Customs. Also taking photos of them with no covering at all, representing them to be wild bush Natives in Central Australia and they do not get around like that here at Ooldea'. ${ }^{145}$

Firth's assertion of the importance of the research programme points not only to the power of gatekeepers like Neville, but at the same time highlights the positioning of anthropology as a discipline which, while encouraging understanding and helping government in the control and care of Aboriginal people, saw the capture of knowledge to be of greater importance than bringing the treatment and conditions of Aboriginal people under government protection to public attention. ${ }^{146}$ He also makes an argument for the pragmatic everydayness of these decisions about dealing with government and agents. But as Piddington learnt - and others, such as Ronald and Catherine Berndt, who were instructed by his example - a career in anthropology in Australia required silence about what they often witnessed or were privileged to hear. ${ }^{147}$

In Kaberry's case, her elision regarding conditions and treatment of Aboriginal people, consciously or not, benefited her career: she was offered a position in Australia

\footnotetext{
143. Kaberry to Mary Durack, 14 February 1939, DP.

144. Elkin 1938: v; Merlan 1988; Cf Toussaint 1999.

145. HE Green to Aborigines' Protection Board, 20 September 1941. State Archives of South Australia, GRG 52/1/1941/25. As a result of Green's representations the Berndts' permit was withdrawn.

146. Cf Marcus 1992: 114

147. Cf Firth 1998: 40-42; Toussaint 1999: 71.
} 
if she wanted it but the declaration of war in September 1939 led to the position being withdrawn. In contrast, Piddington was pushed into permanent exile, returning only briefly to Australia toward the end of the war in the Pacific before returning to Britain. Kaberry's adaptability also enabled the Department of Anthropology at the University of Sydney to maintain good relations with the Department of Native Affairs in Western Australia. As Elkin had promised, Kaberry caused no problems for either the settlers, the government or the Aboriginal people. Research could continue without interruption as long as funds were available.

\section{Acknowledgments}

A version of this paper was first presented to a seminar at the Australian Institute of Aboriginal and Torres Strait Islander Studies, September 2000. A revised version was presented at the ANU in September 2001. I would like to thank Michael Rowland, Kaberry's literary executor, for permission to use material from Kaberry's field notes and correspondence; John Stanton and Sandy Toussaint for access to Kaberry's letters in the Durack Papers, Berndt Museum, University of Western Australia; Bruce Rigsby, Fiona Paisley, Christine Cheater, Nicolas Peterson, Gillian Cowlishaw, Bob Tonkinson and Christine Winter discussed many of the ideas in this paper. I would also like to thank an anonymous referee for raising some issues concerning the practice of anthropology which helped make this paper better. Also Ingereth Macfarlane for editorial assistance. This does not mean that they necessarily agree with the ideas expressed in this article.

\section{References}

\section{Primary sources}

Australian Board of Missions (ABM), Papers, Mitchell Library, Sydney.

Australian Institute of Aboriginal and Torres Strait Islander Studies (AIATSIS), Canberra.

Australian National Research Council (ANRC) Papers, Australian National Library (ANL), Canberra.

Durack papers (DP), Berndt Museum, University of Western Australia.

Elkin Papers (EP), University of Sydney Archives, Sydney.

Hogbin Papers, University of Sydney Archives, Sydney.

United Evangelical Lutheran Church in Australia (UELCA) Archives, Adelaide.

National Archives of Australia (NAA), Canberra and Melbourne.

State Archives of South Australia, Adelaide.

Thomson Collection, Museum of Victoria, Melbourne.

Western Australia State Archives (WASA), Perth.

West Australian newspaper

Sydney Morning Herald newspaper

\section{Secondary sources}

Asad, Tal (ed) 1973, Anthropology and the Colonial Encounter, Ithaca Press, London. 
Beckett, Jeremy 2001, 'Against the grain: fragmentary memories of anthropology in Australia, 1956-1970', in Geoffrey Gray (ed), Before it's too late: anthropological reflections 1950-1970, Oceania Monographs, Sydney: 82-100.

Berndt, Catherine 1988, 'Phyllis Mary Kaberry (1910-1977)', in Ute Gacs, Aisha Khan, Jerrie McIntyre, Ruth Weinberg, (eds), Women anthropologists: a biographical dictionary, Greenwood Press, New York.

Berndt, Ronald 1967, 'Social anthropology and Australian Aborigines', Oceania 37 (4): 244-259.

- 1983-84, 'Practical anthropology in Australia: some personal comments', Anthropological Forum 5(2): 161-175.

Biskup, Peter 1973, Not slaves not citizens: the Aboriginal problem in Western Australia 1898-1954, University of Queensland Press, St Lucia.

Burridge, Kenelm, 1973, Encountering Aborigines: a case study: anthropology and the Australian Aboriginal, Pergamon Press, New York.

Cheater, Christine 1993, 'From Sydney school girl to African queen mother: tracing the career of Phyllis Mary Kaberry', in Julie Marcus, (ed), First in their field: women and Australian anthropology, Melbourne University Press, Melbourne: 137-158.

Cocks, Paul 1994, 'The rhetoric of science and the critique of imperialism in British social anthropology, ca. 1870-1940', Paper presented to the Anthropology department, La Trobe University. Unpublished paper (in author's possession).

Cowlishaw, Gillian 1987, 'Colour, culture and the Aboriginalists', Man (NS) 22: 221-237.

---1997, 'Race at work: reflecting on fieldwork in the Northern Territory', Journal of the Royal Anthropological Institute (N.S.), 3: 95-113.

---1999, Rednecks, eggheads and blackfellas, Allen \& Unwin, Sydney.

Durack, Mary 1959, Kings in grass castles, Constable \& Co, London.

Duckham, Ian 2000, 'Visionary, vassal or vandal? Rod Schenk - a case study of Western Desert Missions', Limina, 6: 41-56.

Elkin, AP 1935a, 'Anthropology and the Australian Aboriginal', in JS Needham, (ed), White and Black in Australia, National Missionary Council, London: 13-37.

- 1935b, 'Anthropology in Australia, past and present', (Presidential Address to Section F), Report of the twenty-second meeting of the Australian and New Zealand Association for the Advancement of Science 22: 196-207.

----1938, The Australian Aborigines. How to understand them, Angus \& Robertson, Sydney.

-_-_-1939, 'Anthropology in Australia, 1939', Oceania 10(1): 1-29.

---1962, 'Australian Aboriginal and white relations: a personal record', Royal Australian Historical Society Journal 48(3): 208-230.

-1965, 'Address to the first General Meeting of AIAS, October 1964, AIAS Newsletter 2(1): 11-23.

1994 'Aboriginal-European relations in Western Australia: an historical and personal record', in Ronald Berndt and Catherine Berndt, (eds), Aborigines of the west: their past and their present, University of West Australia Press, Nedlands: 285323. 
Firth, Raymond 1998, 'Anthropologists and Aborigines 65 years ago', Australian Aboriginal Studies, 1/1998: 40-42.

Gledhill, John 2000, Power and its disguises: anthropological perspectives on politics, Pluto Press, London.

Gray, Geoffrey 1994, 'Piddington's indiscretion: Ralph Piddington, the Australian National Research Council and academic freedom', Oceania 64(2): 217-245

— 1997a, “"Mr Neville did all his power to assist me”: AP Elkin, AO Neville and anthropological research in northwest Western Australia, 1927-1928', Oceania 68(1): 27-46.

— 1997(b), “"[I]n view of the obvious animus": the discrediting of Ralph Piddington', Aboriginal History 21: 123-142.

— 1998, '(This often) sympathetic collaboration: anthropologists, academic freedom and government', Humanities Research 2: 37-61.

— 1999, “"Being honest to my science”: Reo Fortune and JHP Murray, 1927-30', The Anthropological Journal of Australia 10(1): 56-76.

- 2000, '[The Sydney school] seem[s] to view the Aborigines as forever unchanging: southeastern Australia and Australian anthropology', Aboriginal History 24: 176200.

- (ed) 2001a, Before it's too late: anthropological reflections, 1950-1970, Oceania Monograph no. 51,Oceania Publications, Sydney.

- 2001b, 'Abrogating responsibility? Applied anthropology, Vesteys, Aboriginal labour, 1944-1946', Australian Aboriginal Studies, 2/2001: 27-39.

Hogbin, H Ian 1932, 'Anthropology and the native problem', 15 and 17 September, Sydney Morning Herald.

Jacobs, Pat 1986, 'Science and veiled assumptions: miscegenation in WA 1930-1937', Australian Aboriginal Studies, 2/1986: 15-23.

— 1990, Mr Neville. A biography, Fremantle Arts Press, Fremantle.

James, Wendy 1973, 'The anthropologist as reluctant imperialist', in Tal Asad, (ed), Anthropology and the colonial encounter, Ithaca Press, London: 41-70.

Kaberry, Phyllis 1935, 'The Forrest River and Lyne River Tribes of North-West Australia. A report on fieldwork', Oceania 5(4): 408-437.

- 1939, Aboriginal woman: sacred and profane, Routledge, London.

Kuper, Adam 1996, Anthropology and anthropologists: the modern British school, Routledge, London.

McLean, Ann 1992, 'In the footprints of Reo Fortune', in Terence E Hays, (ed), Ethnographic presents: pioneering anthropologists in the Papua New Guinea highlands, University of California Press, Los Angeles: 37-67.

McKnight, David 1990, 'The Australian Aborigines in anthropology', in Richard Fardon, (ed), Localising strategies, Scottish Academic Press, Edinburgh: 42-70.

Marcus, Julie 1987, 'Olive Pink and the encounter with the Academy', Mankind 17(3): 185-197.

1992, 'Racism, terror and the production of Australian auto/biographies', in Judith Okely and Helen Callaway, (eds), Anthropology and autobiography, ASA Monographs 29, Routledge, London: 100-115. 
---2001, The indomitable Miss Pink: a life in anthropology, University of NSW Press, Sydney.

Merlan, Francesca 1988, 'Gender in Aboriginal social life: a review', in RM Berndt and R Tonkinson, (eds), Social anthropology and Australian Aboriginal studies. A contemporary review, Aboriginal Studies Press, Canberra: 17-76.

Morgan, Margaret 1986, A drop in the bucket. The Mount Margaret story, Mission Publications of Australia, Lawson.

Mulvaney, DJ 1988, 'Australasian anthropology and ANZAAS: "strictly scientific and critical"', in Roy MacLeod, (ed), The Commonwealth of science: ANZAAS and the scientific enterprise, 1888-1988, Oxford University Press, Melbourne: 196-221.

Paisley, Fiona 2000, Loving protection?, Melbourne University Press, Melbourne.

Piddington, Marjorie and Ralph Piddington 1932, 'Report of field work in north-west Australia', Oceania 2(3): 342-358.

Piddington, Ralph 1936, 'Report of the Royal Commissioner appointed to investigate, report and advise upon matters in relation to the condition and treatment of Aborigines (Western Australia)', Man 258: 196-97.

Reay, Marie 1963, 'The social position of women', in Helen Shiels, (ed), Australian Aboriginal studies: a symposium of papers presented at the 1961 research conference, Oxford University Press, Melbourne.

---- (ed) 1964, Aborigines now. New perspective in the study of Aboriginal communities, Angus \& Robertson, Sydney.

Reynolds, Henry 1998, This whispering in our hearts, Allen \& Unwin, Sydney.

Stanner, WEH 1969, After the Dreaming. Black and white Australians - an anthropologist's view, Australian Broadcasting Commission, Sydney.

Thomas, Cora 1994, 'From “Australian Aborigines" to "White Australians": Elkin, Hasluck and the origins of assimilation', MA thesis, Monash University, Melbourne.

Thomas, Nicholas 1994, Colonialism's culture, Melbourne University Press, Melbourne.

Thomson, Donald 1948-49, 'Arnhem Land: explorations among an unknown people', parts 1, 2 and 3, The Geographic Journal vol. 112 1948: 146-164, vol. 113 1949: 1-8, 53-67.

----1983: Donald Thomson in Arnhem Land, compiled and introduced by Nicolas Peterson, Curry O'Neil, Melbourne.

Toussaint, Sandy 1999, Phyllis Kaberry and me, Melbourne University Press, Melbourne.

Warner, W Lloyd 1937, A black civilisation: a social study of Australian tribe, Harper \& Brothers.

Warner, WL, AR Radcliffe-Brown, and FW Burton 1928, 'Some aspects of the Aboriginal problem in Australia', The Australian Geographer 1: 68-69.

Wetherell, David 1977, Reluctant mission: the Anglican Church in Papua New Guinea, 18911942, University of Queensland Press, St Lucia. 